Summer 2003

\title{
A Critical Methodology of Globalization: Politics of the 21st Century?
}

Vidya S. A. Kumar

Follow this and additional works at: https://www.repository.law.indiana.edu/ijgls

Part of the International Law Commons, and the Law and Politics Commons

\section{Recommended Citation}

Kumar, Vidya S. A. (2003) "A Critical Methodology of Globalization: Politics of the 21st Century?," Indiana Journal of Global Legal Studies: Vol. 10 : Iss. 2 , Article 4.

Available at: https://www.repository.law.indiana.edu/ijgls/vol10/iss2/4

This Article is brought to you for free and open access by the Law School Journals at Digital Repository @ Maurer Law. It has been accepted for inclusion in Indiana Journal of Global Legal Studies by an authorized editor of Digital Repository @ Maurer Law. For more information, please contact rvaughan@indiana.edu.

\section{$\Psi$}

JEROME HALL LAW LIBRARY

INDIANA UNIVERSITY

Maurer School of Law
Bloomineton 


\title{
A Critical Methodology of Globalization: Politics of the 21st Century?
}

\author{
VIDYA S. A. KumaR*
}

With international protests against globalization occurring almost as frequently as the term "globalization" is uttered, the fundamental question of what globalization is seems to have been eclipsed by promulgations of its arrival. Globalization, as proponents and protesters alike proclaim, is upon us, forcing us to determine what, if anything, must be done about it. This article will argue that the debate about what to do about globalization is still very much a debate about what globalization is. My aim is to reflect, from an interdisciplinary perspective, upon the intimate relationship between how globalization is defined and what globalization theorists propose as appropriate responses to its effects, positive or negative. This article is divided into four parts. Part I distinguishes between two uses of the term "globalization," and articulates the focus of the article in light of that distinction. Part II maps some of the multifarious and, at times, contradictory definitions of globalization articulated by globalization theorists across the disciplines of sociology, law, political science, social theory and economics.' Part III analyzes whether a relationship exists between the activities of globalization description and prescription, ${ }^{2}$ and Part IV then articulates the need for a critical methodology of globalization that accounts for this relationship.

\footnotetext{
* D.Phil. Candidate, Faculty of Law, Oxford University, England; LL.M., Osgoode Hall Law School, Toronto, Ontario, Canada; LL.B. and B.A. (Hons.), Queen's University, Kingston Ontario, Canada; M.A., University of Alberta, Edmonton, Alberta, Canada. This is a version of a paper given on March 18, 1999, in Cape Town, South Africa at I.N.T.E.L.L.'s (International Network of Transformative Employment and Labour Law) Fourth Annual Conference on "Globalization, Labour Law and Equity."

1. This Part draws on a random sample of recent globalization literature, books and articles. The article's analysis is limited to recent publications on globalization, and collated definitions from a cross-section of academic disciplines, and does not privilege any particular one.

2. In this paper, I employ the terms "response" and "strategy" interchangeably. Both terms refer to the ways in which people choose to address "globalization." "Prescription" means advocating, implicitly or explicitly, for or against a specific course of action.
} 


\section{Distinguishing Between “Capital-G” and "Small-g" Globalization}

The ubiquity of the term "globalization" is beyond debate and almost seems trite to mention. ${ }^{3}$ Globalization theory - the study of globalization-is a "new academic industry," firmly ensconced in most disciplines, including the humanities, social sciences, and physical sciences. ${ }^{4}$ This may not be surprising if one considers that the term "globalization" has been around over forty years, first appearing in Webster's Dictionary in $1961 .{ }^{5}$ Despite its age, or perhaps because of it, it would be a difficult, if not indomitable, task to completely capture the multiplicity of meanings connoted by the term "globalization."

One analytical way to manage the enormity of this task is to distinguish between capital-G "Globalization" and small-g "globalization." That is to say, it may be conceptually helpful to presume a distinction between what is actually happening globally-globalization-and what globalization theorists describe as occurring globally-Globalization. This strategy builds on James H. Mittelman's assertion that globalization may be both an "objective and subjective phenomenon." Accordingly, this paper argues that globalization theorists attempt to define globalization, but in so doing, they create Globalization. ${ }^{7}$ This approach recognizes that the study of Globalization is as important, if not more so, as that of globalization, in so far as it explicitly recognizes the role that globalization theorists play in the construction of social understandings or facts about globalization.

Admittedly, there are limitations to this approach. First, by making this analytic distinction, one avoids having to answer the contentious question of whether the definition of globalization propounded by a particular globalization theorist is accurate-whether it squares with reality. Although this is an important question, it is beyond this article's scope (and others seem to be

3. "There is no doubt about it: Globalization is the buzz word of the decade. Journalists, politicians, business executives, academics, and others are using the word to signify that something profound is happening, that the world is changing, that a new world economic, political and cultural order is emerging." Douglas Kellner, Globalization and the Postmodern Turn, in Globalization and Europe: Theoretical and Empirical Investigations 23 (Roland Axtmann ed., 1998) [hereinafter Globalization and Europe].

4. William Twining, Globalization and Legal Theory 6 (2000) [hereinafter Legal Theory].

5. Richard Kilminster, Globalization as an Emergent Concept, in The Limits of Globalization: Cases and Arguments 257 (Alan Scott ed., 1997) [hereinafter The Limits of Globalization].

6. James H. Mittelman, How Does Globalization Really Work?, in 9 Globalization: Critical. Reflections 229, 230 (James H. Mittelman ed., 1996).

7. This is true irrespective of whether they successfully (i.e. accurately) define "globalization." 
answering it elsewhere $\left.{ }^{8}\right)$. My purpose is much narrower. I intend to survey an interdisciplinary sample of definitions of globalization not necessarily to juxtapose their similarities and differences with each other or with reality, but rather to uncover the relationship between the theorists' descriptions and prescriptions about globalization. Given this limited purpose, I am primarily concerned with how Globalization is being characterized by globalization theorists and what, if anything, this implies.

Second, it is important to underscore that this article does not present an authoritative definition of globalization, although it does examine the definitions of globalization propounded, and the methodologies employed, by the globalization theorists surveyed. Moreover, this article does not intend to join the debate as to whether or not globalization exists, and, if so, what the term means. For better or for worse, this article will presume that it does, ${ }^{9}$ although this is certainly a live issue among globalization theorists. ${ }^{10}$ To summarize, the limitations of this article's focus on globalization are twofold: it will neither evaluate the accuracy of existing definitions of globalization, nor proffer an authoritative definition of the term.

8. See, e.g., Wayne Ellwood, The No-Nonsense Guide to Globalization (2001); Ulrich Beck, What is Globalization? (2000); Daniel Drache, Globalization: Is There Anything to FEAR? (Centre for the Study of Globalisation and Regionalisation, Univ. of Warwick, Working Paper No. 23/99, 1999).

9. At the very least, globalization appears to be "the designation of our epoch." Mehdi Mozaffari, Mega Civilization: Global Capital and the New Standard of Civilization, in THE NEw MilleNnium: Challenges and Strategies for a Globalizing World 19 (S.F. Krishna-Hensel ed., 2000) [hereinafter The New Millennium].

10. Compare Paul Hirst \& Grahame Thompson, Globalization in Question: The International Economy and the Possibilities of Governance 2 (2d ed. 1992) ("[W]e became convinced that globalization, as conceived by the more extreme globalizers, is largely a myth."), and LEGAL THEORY, supra note 4, at 7 ("[I]t is widely agreed that the processes of globalization are not entirely new."), and Boaventura de Sousa Santos, Oppositional Postmodernism and Globalizations, 23 LAw \& Soc. INQUiRY 121, 135 (1998) ("There is no single entity called globalization; there are, rather, globalizations, and we should use the term only in the plural. . . What we call globalization is always the successful globalization of a given localism"), with Anki e Hoogvelt, Globalisation and the Postcolonial World: The New Political Economy of Development 114-15 (arguing that globalization today has meaning as a deepening of economic activity worldwide, as opposed to an extension of it), and John Micklethwait \& Adrian Wooldridge, A Future Perfect: The Challenge and Hidden Promise of Globalization xvi (2000) ("Globalization has become ... the most important economic, political, and cultural phenomenon of our time. . . [ [t] is neither new nor complete ... [and] has begun to assume mythical overtones."). 


\section{II. “Globalization" Cartography}

\section{A. Problem of Definition}

"There are today so many definitions of globalization that one would think that defining it is an easy task. In fact, this is not the case."Il Remarkably, I found a virtually unanimous awareness among the globalization theorists canvassed of the difficulties inherent in defining globalization. These theorists observed that "globalization theories draw on a variety of different and sometimes contradictory perspectives," 12 that there is "considerable disagreement over definitions of globalization," 13 that the nature of globalization is contingent upon one's theoretical perspective, ${ }^{14}$ that there are "emergent" competing conceptual explanations of globalization, ${ }^{15}$ that "depending upon the observer's preferences, [globalization] is understood and interpreted differently," 16 that "the term is often used very loosely and ... in contradictory ways," 17 and that "there is no consensus on a common interpretation of the nature of globalization." 18 Although some theorists avoid defining the term altogether, ${ }^{19}$ most grapple with

11. Santos, supra note 10 , at 134 . The opposite view, also articulated to underscore the term's ambiguity, is asserted by Micklethwait and Wooldridge. "[E]verybody invokes [globalization], but nobody will define it." Micklethwait \& Wooleridge, supra note 10, at xvi.

12. J. Grugel \& W. Hout, Regions, Regionalism, and the South, in Regionalism Across the North-South Divide: State Strategies and Globalization 5 (J. Grugel \& W. Hout eds., 1999).

13. John Eade, Introduction to Living the Global City: Globalization as a Local Process 3 (John Eade ed., 1997) [hereinafter Living The Global City]. In addition, Eade notes that, in this disagreement, "a prime concern among commentators has been the compression of time and space." Id.; see also Kellner, supra note 3, at 23 (emphasizing that the term globalization is used in so many different contexts by so many different people).

14. The Globalization of World Politics: An Introduction to International Relations 610 (John Baylis \& Steve Smith eds., 1997) [hereinafter The Globalization of World Politics]. The authors identify "three theories of globalization," "Realism," "Liberalism," and "WorldSystem Theory," each of which identifies salient aspects of globalization and argues that it provides a better account of globalization than its rival theories. Id. at 6-7.

15. Kilminster, supra note 5 , at 261.

16. Mozaffari, supra note 9 , at 19.

17. Roland Robertson, Globalization: Social Theory and Global Culture 8 (1992).

18. S.F. Krishna-Hensel, Globalization and the International System, in The New Millennium, supra note 9 , at 5 .

19. See, e.g., N.J. Alder, Globalization, Government and Competitiveness: The John L. Manion Lecture (1994); Daniel. Judah Elazar et al., Constitutionalizing Globalization: 
the unpleasant task of definition, cognizant of the hurdle it poses. For example, sociologist Cesare Poppi noted that:

The literature stemming from the debate on globalization has grown in the last decade beyond any individual's capability of extracting a workable definition of the concept. In a sense the meaning of the concept is self evident, in another, it is as vague and obscure as its reaches are wide and constantly shifting. Perhaps, more than any other concept, globalization is the debate about it. ${ }^{20}$

For the most part, globalization theorists appear intimately aware of the plethora of competing Globalization definitions and of the difficulties attached to the project of creating a unified and comprehensive definition. Nevertheless, they have been little deterred from proffering their own authoritative definitions of globalization.

\section{B. Mapping "Globalization"}

Although the prevalence of the term "globalization" makes it "both a popular idea and a concept lacking specificity," ${ }^{21}$ purportedly authoritative definitions are not difficult to find. In this part, I will canvass a limited selection of definitions garnered from my survey of recent globalization literature. As mentioned previously, these definitions traverse the fields of sociology, economics, law, politics, and social theory, and are provided with one aim in mind: to ascertain whether a link (or many links) can be made between what globalization theorists describe and prescribe.

In the literature examined, the essential nature of globalization is described in overlapping ways, and characterized by all sorts of adjectives and metaphors. Some globalization theorists have described globalization as a "condition." 22

The Postmodern Revival of Confederal Arrangements (1998). But see Paul Streeten, Globalization: Threat or Salvation?, in Globalization, Growth and Marginalization 13 (A.S. Bhalla ed., 1998) (setting out the central components of globalization).

20. Cesare Poppi, Wider Horizons with Larger Details: Subjectivity, Ethnicity and Globalization, in The Limits of Globalization, supra note 5, at $300 \mathrm{n} .1$ (emphasis in original).

21. Jane Jenson \& Boaventura de Sousa Santos, Introduction: Case Studies and Common Trends in Globalizations, in Globalizing Institutions: Case Studies in Regulation and Innovation 9 (Jane Jenson \& Boaventura de Sousa Santos eds., 2000) [hereinafter Globalizing Institutions].

22. Poppi, supra note 20, at 285; see also M. Albrow et al., The Impact of Globalization on Sociological Concepts: Community Culture and Milieu, in Living the Global Ciry, supra note 13, at 20. 
Other theorists have described it as a "phenomenon,"23 others, a "stage"24 or "phase," ${ }^{25}$ others still a "discourse," 26 an "ideology," or "a series of waves, rather like the industrial revolution." ${ }^{28}$ By far the most common depiction of the nature of globalization is that it is one "process," or many "processes." ing potential conflicts of meaning between these descriptions, globalization theorists often employ a combination of them, ${ }^{30}$ sometimes doing so at the risk of circularity. ${ }^{31}$ These descriptions employ interesting metaphors-many evolutionary or teleological (a stage or phase), others naturalistic (a condition, or "a series of waves," "the skin of an orange"32), and others humanizing or anthropomorphic (a discourse or an ideology). These very general characterizations of the nature of globalization create a foundation upon which more specific aspects of globalization rest.

23. Poppi, supra note 20, at 284; A.S. Bhalla, Introduction, in Globaliztion, Growth and Marginalization, supra note 19 , at 1.

24. Richard Langhorne, The Coming of Globalization: Its Evolution and Contemporary Consequences 2 (2001) ("Globalization is the latest stage. ...").

25. Bhalla, supra note 23 , at 1 .

26. Poppi, supra note 20, at 284; see also Kilminster, supra note 5 at 271-72 (seeing globalization as a part of a discourse of concepts); Kellner, supra note 3, at 25 (discussing how the discourse of globalization is neutral on the surface); Eade, supra note 13, at 3 (pointing out that globalization is a part of a transnational discourse).

27. Robert W. Cox, A Perspective on Globalization, in Globalization: Critical Reflections, supra note 6 , at 23.

28. Micklethwait \& Wooleridge, supra note 10 , at xviii.

29. Poppi, supra note 20, at 285 ("dialectical (and therefore contradictory) process"); see also Streeten, supra note 19, at 45; James M. Boyers, Globalization and the United States Constitution: How Much Can it Accommodate?, 5 Ind. J. Global Legal Stud. 583 (1998); Kellner, supra note 3, at 23-24; The Globalization of World Politics, supra note 13, at 7; Eade, supra note 13, at 14-15; C. Murphy, Globalization and Governance: A Historical Perspective, in Globalization and Europe, supra note 3, at 144-45; Hoogvelt, supra note 10, at 131; Anthony G. McGrew, Global Legal Interaction and Present-Day Patterns of Globalization, in Emerging Legal Certainty: Empirical Studies on the Globalization of Law 327 (V. Gessner \& A.C. Budak eds., 1998).

30. One debate about globalization centers around whether it is the cause or the effect of other social phenomena, some arguing it is both: "Thus globalization has come to mean both an ongoing process and a contemporary condition, the result of that process." LANGHORNE, supra note 24, at 2; see also S.F. Krishna-Hensel, International System, in The New MillenNium, supra note 9, at 5 ("It is possible to view globalization as a facilitator of rapid change as well as the condition resulting from change.").

31. Justin Rosenberg, The Follies of Globalisation Theory 2 (2000) ("Globalisation as an outcome cannot be explained simply by invoking globalisation as a process tending towards that outcome.").

32. Krishna-Hensel, supra note 30 , at 15. 
The following section maps definitions of globalization across different disciplines. ${ }^{33}$ Generalizations from this analysis about how differing disciplines define globalization should be made with extreme caution, as this overview is not intended to provide an exhaustive or even a comprehensive sample from each field of study. In an attempt to make its analysis both manageable and meaningful, this article's foray into Globalization theory is cursory at best. It aims simply to provide a sufficient amount of Globalization fodder to answer the following question: Is there a relationship between globalization description and prescription, and, if so, what, if anything, does this relationship imply?

\section{Sociology}

Although sociological definitions of globalization, ostensibly boasting "scientific" significance, ${ }^{34}$ are plentiful, ${ }^{35}$ only three such definitions will be examined here. Sociologist Richard Kilminster identified three definitions of globalization within the discipline of sociology, ${ }^{36}$ ultimately endorsing the third as the best definition. ${ }^{37}$ His preferred conception of globalization proposed a balance between economic and cultural explanations of globalization (evinced by

\footnotetext{
33. Some of these definitions have been truncated for brevity. It must be emphasized that what follows is simply a tasting menu of Globalizations-mere snippets from an infinite, seemingly replete, sea of globalization literature.

34. Kilminster, supra note 5, at 272 ("The sociological concept of globalization is a more systematic version taken up from everyday usage and employed as a scientific concept.").

35. Generally speaking, sociologists have argued that globalization is about the compression of time and space created by a host of factors, including innovations in technology and telecommunications, global cultural migration, the production and consumption of images and services as opposed to goods, crises in over-accumulation, and cultural and political formulations. See Eade, supra note 13, at 7-10 (regarding Eade's discussion of David Harvey, Scott Lash, John Urry, Stuart Hall and Doreen Massey). Others have said that when sociologists discuss globalization, they:
}

debate the extent to which one can posit the existence of a more or less homogeneous global civil society as the world has become more united, variously, by political struggle and patterns of mobilization which transcend the boundaries of the national, by Westernization, McDonaldization, Coca-Colonisation and American cultural imperialism, by heightened or "reflexive modernization," post-modernization or neo-Medievalism.

Colin Hay \& David Marsh, Introduction: Demystifying Globalization, in Demystify ING GlobalizaTION 2 (Colin Hay \& David Marsh eds., 2000).

36. Kilminster, supra note 5, at 258-59.

37. Id. at 261. 
the first ${ }^{38}$ and second ${ }^{39}$ sociological conceptions of globalization respectively), and "stressed the importance of humankind as a whole ... as well as the related conception of social integrative levels sui generis." ${ }^{40}$ For him, "[g]lobalization is ... an emergent concept ... created spontaneously to reflect people's experiences of the properties of an accelerating phase of the level of social integration compromising the bonds between nation states." ${ }^{41}$ In addition to the increasing pace of integration, globalization indicates that "the transnational level ... [is] becoming increasingly autonomous, such that processes at the lower integrative levels (nation state, region, community, kinship) are in the present period becoming increasingly governed by the order of the higher level." ${ }^{\prime 2}$ The result is that "increasingly the range of decisions which can be taken at the nation-state level is decreasing as the continental and global levels increase in size and complexity." ${ }^{43}$ In essence, Kilminster's Globalization signifies changes in the pace and nature of social integration within nation-states and the increasing governance of this integration by autonomous transnational processes.

38. The first sociological conception of globalization he identified was primarily economic. It focused upon "I $t$ ]he effects of the international division of labour in the generation of a structure of inequality between nations," and maintained that the economic logic of capital accumulation in the larger capitalist world economy largely determines social events and political changes within nations. Id. at 258 .

39. The second sociological conception of globalization Kilminster names focuses upon " $[t]$ he role of culture, including the globalization of information and communication, in shaping world reality." Id. at 258.

The argument of this [conception] is that a more unified picture of the globalizing process must embrace the counter-movements and traditional-communal reactions, which are organic to the process, for which we need a concept of culture. At the same time, we must look at the level of transnational institutions and the creation of international legal norms for any observable harbingers of the emergence of a genuinely global human solidarity. Id. at 259.

40. Id. at 259. Inter alia, it sought to provide an "explanatory relationship between the figurational compulsion of the network of interdependent nations and international violence; the formation of We- and I- identities (and/or we- and I- self-images); and codes of interpersonal behaviour." Id. Specifically, this conception emphasized "Ir]he part played by symbolic representations, political culture, information technology, the global media and religious countermovements," and attempted to "capture the contradictory interplay of 'particularism' and 'universalism'." Id. at 258-59.

41. Id. at 272 .

42. Id. at 271 .

43. $1 d$. 
Other sociologists have tackled the definition of globalization differently. Although Cesare Poppi asserts the impossibility of coming up with a "workable" definition of globalization, ${ }^{44}$ he nevertheless insists that globalization is both a historically observable phenomenon and a discourse about it. ${ }^{45}$ In characterizing globalization as a historically observable phenomenon, he claims:

[G]lobalization must be understood as the condition whereby localizing strategies become systematically connected to global concerns.... Thus, globalization appears as a dialectical (and therefore contradictory) process: what is being globalized is the tendency to stress "locality" and "difference", yet "locality" and "difference" presuppose the very development of worldwide dynamics of institutional communication and legitimation. ${ }^{46}$

Thus, Globalization is partly a condition whereby "localizing strategies" attach to global issues, and partly a global process accentuating "locality" and "difference." ${ }^{47}$ Poppi also asserts that globalization is a "discourse," not only as a debate about itself as a concept, but also a discourse that "creates what is coterminous with it." 48 Here, the debate about globalization becomes a criterion of its definition. For Poppi, all this means that the definition of globalization "cannot be accepted or rejected: it is a historical development, which is also the precondition

44. "In the present chapter, therefore, I will not give 'a definition' as is customary in AngloAmerican sociology. I would rather let the concept 'do its work' by focusing on its conditions of existence on the one hand, and on its implications on the other." Poppi, supra note 20, at $300 \mathrm{n}$. I.

45. Id.

46. Id. at 285 .

47. The relationship of globalization to "locality" has been addressed previously by other scholars. For example, two years earlier, legal sociologist Boaventura de Sousa Santos provided the following two-pronged definition of globalization:

I distinguish two forms of globalization.... The first one I would call globalized localism. It consists of the process by which a given local phenomenon is successfully globalized... The second form of globalization I would call localized globalism. It consists of the specific impact of transnational practices and imperatives on local conditions that are thereby destructured and restructured in order to respond to transnational imperatives.

Boaventura de Sousa Santos, Toward a New Common Sense: Law, Science and Politics in The Paradigmatic Transition 263 (1995).

48. Poppi, supra note 20, at 284. 
for it becoming the subject of sociological investigation." ${ }^{49}$ Rather, "[t]he problem $\ldots$ is to what extent the concept ... of 'globalization' is or is not a useful tool to understand and explain certain central developments of late capitalist society."

The last sociological definition of globalization examined in this article is articulated by Roland Robertson. Robertson asserts that globalization "refers both to the compression of the world and the intensification of consciousness of the world as a whole." ${ }^{51} \mathrm{He}$ advocates that "we have to conceive of the concept of globalization as having primarily to do with the form in terms of which the world has moved towards unicity." 52 That is to say, "when we speak of globalization we must realize that we are referring above all to a relatively specific path that the world has taken in the direction of it becoming singular." ${ }^{.53}$ Robertson adopts a "cultural perspective on globalization," 54 defending this emphasis in the following passage:

In arguing that mine is a cultural perspective on globalization I do not wish to convey the idea that I consider the matter of "the forces" or "the mechanisms" of globalization unimportant. However, I am well aware that that is well-trodden ground. The spread of Western capitalism and the part played by imperialism have been addressed at great length, as has the increasingly complex crystallization of the contemporary global economy. ${ }^{55}$

Here Robertson explains that a focus upon the cultural dimension of globalization does not lessen the importance of the forces undergirding it, i.e. Western capitalism, imperialism, and the crystallization of the global economy. In sum, the Globalizations presented by sociologists Kilminster, Poppi, and Robertson focus on diverse social variables and processes, such as social integration, culture, economics, capitalism, "locality and difference," the development of a global discourse, and "singularity."

49. Id.

50. Id. (emphasis in original).

51. Robertson, supra note 17 , at 8 .

52. Id. at 175 (emphasis omitted).

53. Id.

54. His cultural approach is "used to demonstrate discontinuities and differences, rather than the traditional sociological view of culture as integrating." Id. at 29.

55. Id. at 28-29. 


\section{Economics}

In asking economists what globalization means, one may be left with a disagreement instead of an answer, as the two economists examined here demonstrate. While noting the contestability of the term, economist A.S. Bhalla identified finite criteria of globalization. For Bhalla, globalization is made up of five "economic" features, and two "non-economic" ones. The economic attributes of globalization include: first, a growth in global trade; second, a growth both in Foreign Direct Investment (FDI) and in capital flows (i.e. portfolio investments); third, a growth in global production and consumption; fourth, the advent of global competition; and last, the proliferation of trade and investment liberalization policies. ${ }^{56}$ The two identifiable "non-economic" characteristics of globalization are the loss of national sovereignty, or the demise of the state, and the unprecedented standardization of values and culture. ${ }^{57}$ In contrast, economist Gijsbert Van Liemt defines globalization simply to be "the growing interdependence of national economies." ${ }^{58}$ For Van Liemt, globalization results from three factors: first, enabling factors-"these are principally faster, cheaper, and more reliable telecommunications and international transport"; second, government policies promoting trade liberalization and external capital liberalization; and last, corporate strategies (e.g. company practices of both selling and purchasing abroad). ${ }^{59} \mathrm{~A}$ superficial glance at these two definitions reveals that, among other things, each economist has a different understanding of the relationship between globalization and the state.

\section{Law}

Legal definitions of globalization are no less varied. One legal scholar, James Boyers, in his piece examining the impact of Globalization on the U.S. Constitution, proffers the following definition of the term: "Globalization 'denotes a

56. A.S. Bhalla, supra note 23 , at $1-6$.

57. Id. at 6-8. The standardization of values and culture is at odds with Poppi's assertion that globalization globally accentuates "difference."

58. Gijsbert van Liemt, Labour in the Global Economy: Challenges, Adjustment and Policy Responses in the $E U$, in Globalization of Labour Markets: Challenges, Adjustment and Policy Response in the European Union and Less Developed Countries 237 (Olga Memedovic et al. eds., 1998).

59. Id. 
process of denationalization of clusters of political, economic, and social activities." ${ }^{60}$ From this definition, he argues that globalization effectively means that a country may no longer "govern itself efficiently without considering its impact on the global community or the global community's impact on it." ${ }^{61}$ In contrast, Anthony G. McGrew's legal analysis of globalization posits the following definition of the term:

[W] can begin to conceive of globalization as a process which generates flows and connections, not simply across nation-states and national territorial boundaries, but between global regions, continents and civilizations. This invites a definition of globalization as: "an historical process which engenders a significant shift in the spatial reach of networks and systems of social relations to transcontinental or interregional patterns of human organization, activity and the exercise of power." 62

Further, McGrew notes the "historically contingent" nature of globalization, by which one's definition of globalization is a function of one's time frame. ${ }^{63}$

\section{Political Science and International Relations}

For a definition of globalization from the viewpoint of political science and international relations, this article will examine the work of John Baylis and Steve Smith. Again, these authors identify competing definitions or theories of

60. Boyers, supra note 29, at 583 (citing Jost Delbrück, Globalization of Law, Politics, and Markets_Implications for Domestic Law-A European Perspective, I Ind. J. Global Lecal Stud. 9, I ( 1993$)$ ) (emphasis omitted).

61. Id. Cf. Boaventura de Sousa Santos, Law and Democracy: (Mis)trusting the Global Reform of Courts, in Globalizing Institutions, supra note 21, at 253 (suggesting that globalization may indeed create a crisis for state governance, but that this has to do with the recent global expansion of judicial power).

62. McGrew, supra note 29 , at 327.

63. "Over the course of world history it is possible to distinguish analytically between distinct historical forms of globalization, from that of the pre-modern age, the early modern era of the voyages of discovery, through the 'long nineteenth century,' to the present era of late modernity. This is not to suggest an evolutionary or teleological account of world history; on the contrary the very concept of historical forms of globalization embraces a view of historical change which stresses discontinuity and contingency." $I d$. at 328 . 
globalization, implicitly recognizing its contestability. ${ }^{64}$ Nevertheless, in an exhaustive overview of the term, they state: "By globalization we simply mean the process of increasing interconnectedness between societies such that events in one part of the world more and more have effects on peoples and societies far away." 65 They also contend that "modernization is a part of the globalization process," ${ }^{66}$ that globalization is likely a stage resulting from economic growth, ${ }^{67}$ that globalization is about economic interdependence, ${ }^{68}$ that globalization encompasses Marshal McLuhan's communications revolution, ${ }^{69}$ that globalization can be about the emergence of a world or international society, ${ }^{70}$ and that globalization can be about Francis Fukuyama's "end of history."71 In sum, they argue that Globalization captures a change in the world, and refers to processes whereby "social relations acquire relatively distanceless and borderless qualities, so that human lives are increasingly played out in the world as a single place." 72 In other words, "[g]lobalization is thus an ongoing trend whereby the world has-in many respects and at a generally accelerating rate-become one relatively borderless social sphere." ${ }^{73}$

For political scientist Richard Langhorne, "[g]lobalization is the latest stage in a long accumulation of technological advance which has given human beings the ability to conduct their affairs across the world without reference to nationality, government authority, time of day or physical environment." ${ }^{74}$ He identifies the first stage of this technological advance as the "application of the steam engine to land and sea transport." 75 The second stage came with the invention of the telegraph. The third stage, "globalization," has resulted from "modern com-

\footnotetext{
64. The Globalization of World Politics, supra note 14, at 6-10.

65. Id. at 7 .

66. $I d$.

67. Id. at 8 .

68. Id.

69. Id.

70. Id.

71. Id.

72. Id. at 14

73. Id. at 15. Compare this with Roland Robertson's inclusion of locality in the definition of globalization, as noted by Eade: "Rather than the local and the global constituting analytical opposites, locality "can be regarded, with certain reservations, as an aspect of globalization." Eade, supra note 13 , at 4.
}

74. LANGHORNE, supra note 24 , at 2 .

75. Id. at 3. 
puter technology," ${ }^{76}$ namely "the development of digital information transfers." 77 "This communications revolution," Langhorne argues, "is the cause of globalization." ${ }^{.78}$ Moreover, globalization is an "ongoing process and a contemporary condition, the result of that process. ${ }^{39}$

\section{Social Theory}

Contemporary social theories, such as neo-Marxism and postmodernism, have produced their own unique definitions of globalization. Neo-Marxist Anki Hoogvelt argues that globalization is not a euphemism for either "internationalization" or "transnationalisation," 80 nor is globalization the expanding phase of capitalism. Rather, globalization is the deepening phase of capitalism. ${ }^{81}$ Globalization indicates that the expansive phase of capitalism is ending, as shown by the declining percentage share of global foreign investments, specifically in Africa and Latin America. ${ }^{82}$ Instead, capitalism is deepening; by this, Hoogvelt means that money is being made out of the very circulation of money and is no longer tied to social relationships concerning production. ${ }^{83}$ Postmodernist theorist Douglas Kellner agrees with his Neo-Marxist counterpart that globalization is really a "phase" or a "stage" that the world has entered. In contrast, however, Keller characterizes this phase not so much as a deepening of capitalism but as a move away from modernity. That is to say, for Kellner, globalization is a state of "betweenness" ${ }^{84}$ in that we are experiencing a shift between modernity and postmodernity that is not yet complete. ${ }^{85}$

\section{Description and Prescription}

Can one discern in the preceding overview a relationship between the activities of globalization description and prescription? This relationship is not clear.

76. Id. at 10 .

77. Id. at 9.

78. Id. at 2 .

79. Id.

80. Hoogvelt, supra note 10 , at 67 .

81. See id. at 85-89.

82. See id. at 78-79.

83. Id. at 128-29.

84. Kellner, supra note 3, at 39.

85. Id. 
Globalization theorists may assert that what they describe as "globalization" has little, if anything, to do with how they want us to respond to it-or even whether they want us to. But the intent to keep the two processes of description and prescription separate, although analytically neat, is not in itself sufficient to ensure such a separation. In fact, it is wishful thinking. The analysis below demonstrates that, despite the differences between academic disciplines, each globalization theorist-simply by the act of defining globalization-delimits the action to be taken to address or respond to globalization. The seeds of strategy concerning globalization are therefore very much bound up with the particular understanding of globalization put forward by the different globalization theorists, irrespective of their particular academic perspectives.

\section{A. Analyzing Globalization Literature}

Looking at the sociological definitions proffered, Richard Klimster explicitly characterizes his conception of globalization as "programmatic" in that it recommends that action be taken in response to globalization. But, because he defines globalization as the accelerated social integration making up the bonds between nation-states, this "action" involves responding to the pace of global social integrative processes. Action concerning non-spatial or non-temporal aspects of globalization must wait for another day. Conversely, Poppi describes globalization as both a discourse and a historical development, neither of which can be accepted or rejected. Accordingly, for him, whether globalization creates positive or negative consequences is beyond normative evaluation. That is, his very definition of globalization denies that it demands a response. Despite his non-evaluative stance, Poppi nevertheless prescribes that globalization, as a discourse, be employed as "a useful tool to understand and explain certain central developments of late capitalist society." ${ }^{86}$ Thus, Poppi's strategy towards globalization is to harness the explanatory potential of language via globalization discourse.

Likewise, definitions of globalization offered by economists ultimately shape the strategies they suggest are available to confront globalization. Both Bhalla and Van Liemt conclude, albeit for different reasons, that the process of globalization is both within and beyond one's control. Bhalla concludes his description of the economic and non-economic attributes of globalization with the

86. Poppi, supra note 20, at 284. 
comment that people can affect some aspects of globalization, while other aspects are simply events that affect people. ${ }^{87}$ Although he acknowledges that it is difficult to separate which aspects are which (i.e. whether trade liberalization is a cause or effect of globalization) ${ }^{88}$ ultimately he concludes that trade liberalization policies are indeed caused by the inevitability of globalization, and are therefore beyond one's control. ${ }^{89} \mathrm{He}$ is able to arrive at this answer because his definition of globalization presumes the loss of state sovereignty. His prescription for globalization was thereby circumscribed by his assumption that globalization necessarily entailed the emasculation of state power.

Unlike Bhalla, Van Liemt concludes that globalization is influenced by government policies, especially those dealing with international capital flows and external trade barriers; the state, in part, "globalizes." Van Liemt notes, however, that the other two factors that constitute globalization-communications and corporate strategies_are simply "spontaneous development" and "there is little that can be done to influence [them]." ${ }^{90}$ Thus, his very definition of globalization removes "communication" and "corporate strategies" from the realm of general strategies addressing globalization. Although there may not be anything remarkable in the fact that these two economists disagree about the state's ability to influence or control globalization, it is noteworthy that this disagreement originates in their definition of globalization.

Legal scholars, too, suggest different strategies to confront different Globalizations. Boyers argues that the U.S. Constitution needs to conform to globalization's imperative of "denationalization," with the proper course of action being a constitutional amendment that achieves this result. ${ }^{91}$ For Boyers, since globaliza-

87. Bhalla argues that these attributes are made up of both endogenous (actions by people/countries) and exogenous (events affecting countries) factors. Bhalla, supra note 23 , at 8 .

88. Id. at 9 ("While the current phase of globalization is no doubt driven by the liberalization of trade and investment policies, particularly by developing countries, it is not always clear whether such liberalization is the cause or the effect of globalization.").

89. Id.

90. van Liemt, supra note 58, at 237; see also Harry W. Arthurs, The Hollowing Out of Corporate Canada?, in Globalizing Institutions, supra note 21, at 29-30.

91. Boyers suggests the following amendment to replace Article II, Section 2, Clause 2 of the U.S. Constitution: "The President shall have the power, by and with the advice and consent of the Senate and the House of Representatives, to make Treaties, to join economic and trade agreements that establish international dispute resolution bodies of special and limited jurisdiction, and to appoint members of such dispute resolution bodies, provided three-fifths of those Representatives and Senators present concur." Boyers, supra note 29, at 599. 
tion requires all countries to consider the global community when governing, the development of national, regional, and world economies requires supra-national organizations. ${ }^{92}$ Were it not for these denationalizing globalizing forces, a constitutional amendment intended to facilitate the integration of the United States into a supra-national framework (e.g. NAFTA) would be unnecessary. ${ }^{93}$ In addition, McGrew's "historically contingent" definition of globalization-which is ostensibly neither "evolutionary" nor "teleological"- "embraces a view of historical change that stresses discontinuity and contingency." ${ }^{\prime 4}$ One implication of this is that "transcontinental or interregional patterns of human organization, activity and the exercise of power" do not conform to any discernable or predictable patterns upon which responses to globalization can be based. ${ }^{95}$ Rather, for McGrew, a response to globalization must confront its unforeseen nature.

Political scientists Baylis and Smith suggest that strategies about globalization really deal with the "increasing interconnectedness" among societies around the world. That is to say, their description of globalization as an "ongoing trend whereby the world has ... become one relatively borderless social sphere" ${ }^{96}$ suggests that strategies concerning globalization focus upon its despacializing tendencies and its corollary effects. In contrast, political scientist Richard Langhorne's assertion that globalization is simply the latest stage in a long accumulation of technological advance implies that future stages will depend on the development and evolution of existing computer and communication technologies. Consequently, one can affect globalization by altering, modifying, regulating, or limiting technology.

Turning to social theory, Hoogvelt does not characterize the state as an impotent actor facing an inevitable globalization. Rather, Hoogvelt's description of globalization as the "deepening" of capitalism" specifically invites government action. Globalization's very existence "depends largely on whether and how national governments resist the process or go along with it." ${ }^{\text {"I }}$ In essence, globalization strategy

92. Id. at 583 .

93. See id. at 598.

94. McGrew, supra note 29, at 328.

95. Id. at 327.

96. The Globalization of World Politics, supra note 14, at 15.

97. Hoogvelt, supra note 10 , at 115-16.

98. Id. at 131; see also Harry W. Arthurs, Labour Law and Industrial Relations in the Global Economy, 18 INdustrial L.J. 571, 582 (1997) (explaining that "globalization would not be possible if states were not prepared to support and facilitate it"). 
on this view depends on whether states continue to actively regulate the market by deregulating it. ${ }^{99}$ By contrast Douglas Kellner's classification of globalization as a phase or stage suggests that it will be outmoded at some unknown point in future. By underscoring the transience of global processes, he creates uncertainty about whether a response to globalization is even necessary. If globalization manifests an incomplete shift from modernity and postmodernity, globalization strategy will be about whether or not (and if so, how) to negotiate this shift.

\section{B. Linking Globalization Description and Prescription}

If there is a relationship between globalization description and prescription, what, if anything, does this relationship imply? The "link" between acts of defining and acts of prescribing suggests that strategy - our idea about what, if anything, we ought to do about globalization-is what is ultimately at stake in globalization theory. But, if one accepts this, what does this conclusion imply? Does the fact that strategy will always be to some extent circumscribed by the act of defining globalization create a crisis for globalization theorists (be they friends or foes of globalization)? Does the contestability of the term "globalization" paralyze theorists' efforts to address the responsibilities created by, the circumstances surrounding, or the repercussions stemming from globalization? Could this mean that globalization should be "post"-ed, following the fate of modernism (post-modernism) and industrialization (post-industrialization)? The answer to each of these questions is no, if one adopts a critical methodology of globalization.

\section{A Critical Methodology of Globalization}

It may not be a coincidence that the difficulty in arriving at a universal or comprehensive definition of globalization comes at a time when "meta-narrative" skepticism is widespread ${ }^{100}$ and contemporary critiques of universalism ${ }^{101}$ enjoy a

99. See Hoogvelt, supra note 10 , at 139.

100. Jean-François Lyotard, The Postmodern Condition 34 (Geoff Bennington \& Brian Massumi trans., 1984). The rise of postmodernist thought is significant to producing theory in that it "forswears the idea of a unique truth." Ernest Gellner, Postmodernism, Reason and ReliGIon at vii (1992).

101. By "universalism," I mean those "totalizing" normative accounts of social relations (which articulate a preferred form of social organization) such as liberalism, capitalism or communism. 
heightened cachet. A singular critical modern theory of anything, let alone one of globalization, ${ }^{102}$ often appears be beyond a theorist's reach. ${ }^{103}$

Nevertheless, many globalization theorists have expressed a need to retheorize globalization, albeit for different reasons. Some have argued that current accounts of globalization focus too strenuously on its "economic aspects" (like familiar deployments of capital) and ignore "new deployments of power" produced by its cultural and political aspects. ${ }^{104}$ Others have argued that globalization theory should be based upon a "civilizational approach" to globalization, as opposed to a "conflict model" based on the "othering" of groups. ${ }^{105}$ Others have argued that we need to move beyond a "proto-theory of globalization" where transnational integration coexists problematically with the persistence of state sovereignty. ${ }^{106}$ Still others have argued that the problem with globalization theory is that, all too often, it confuses the explanandum (that which is explaining) with the explanans (that which is explained). ${ }^{107}$

Without addressing the merit of these claims, I would suggest that globalization needs to be re-theorized for yet a different reason: globalization theorists require an understanding of and approach to description and prescription in globalization theory. Expressing this need another way, one globalization theorist states: "A more complex methodology is required for the study of contemporary globalization, in which socially constructed 'realities' are identified as the basis of a constrained possibilism." 108 In other words, globalization theory needs to address the challenge posed by the connection between description and pre-

102. "Globalization ... seemingly offers fundamental challenges to contemporary legal theory." See Legal Theory, supra note 4, at 10.

103. "The most puzzling problem that the social sciences face today can be formulated like this: If at the close of the century we live in a world where there is so much to be criticized, why has it become so difficult to produce a critical theory?" Santos, supra note 10, at 122.

104. See, e.g., Mohammed A. Bamyeh, The Ends of Globalization 63-64 (2000) ("One of the basic problems with much of the contemporary critique of globalization, both from Left and Right, is their single-minded focus on its rapacious economic aspects.").

105. See, e.g., Farhang Rajaee, Globalization on Trial: The Human Condition and the Information Civilization 10 (2000).

106. Malcolm Waters, Globalization 27-28 (1995).

107. See, e.g., Hay \& Marsh, supra note 35, at 6; see also Rosenberg, supra note 31, at 3 ("In the logical structure of their argumentation, what presents itself initially as the explanandum-globalisation as the developing outcome of some historical process-is progressively transformed into the explanans: it is globalisation which now explains the changing character of the modern world....").

108. R.J.B. Jones, Globalisation in Perspective, in Globalization and Its Critics: Perspectives from International Political Economy 245, 247 (R.D. Germain ed., 2000). 
scription articulated earlier-that globalization strategy is contingent upon and constituted by globalization definition. Specifically this means that globalization theorists can no longer casually recognize the contestability of the term "globalization" without also dealing with the implications of this recognition-the most important of which is that globalization theorists construct strategies. Globalization theorists need to address this implication before moving on to posit a definition of globalization to their audience. How can this done? In order to retheorize globalization to account for the connection between prescription and description, globalization theorists need to adopt a critical methodology of globalization. Such a methodology genuinely accounts for the inherent contestability of the term "globalization," explicitly acknowledges the normative nature of performing globalization theory, and locates its analysis in the (local and global) context of power and inequality.

\section{A. Contestability}

"The term globalization is ... a theoretical construct that is itself contested and open for various meanings and inflections." 109 There are two reasons why it is important for globalization theorists to take the contestable nature of the term "globalization" seriously. ${ }^{110}$ First, the term itself creates a false impression that a shared social language exists and that the multifarious assumptions underpinning globalization are similarly shared. This is particularly true now that globalization has become an omnipresent term, pervading a wide variety of disciplines, including law, sociology, political science, economics, and social theory. The ubiquity of the term tends to lead to a false assumption that audience and author alike agree on the meaning of the term, shifting the preeminent question from "what are globalization's first principles?" to "what (if anything) is our response to a mutually understood globalization?" Globalization theorists have a responsibility to use the term with great care, and to minimize the disconnect between the author's and audience's understanding of the term.

109. See Kellner, supra note 3, at 25.

110. Mere recognition of the contestable nature of the definition of globalization is not enough. Globalization theorists must seriously and sincerely care about the implications of the term's contestability. That is, a globalization theorist must not simply give a nod to the term's contestability and then glibly continue to posit an authoritative definition of the term which denies, ignores, or obscures its problematic essence. 
This leads to the second reason why globalization theorists must expressly recognize the contestability of the term: consensus about the term must be genuine, not imposed. Globalization's first principles-its substance, form, and nature-ought not to be assumed, as one then runs the risk of both poor theory and dishonest communication. Its definitional complexity must be met with a serious effort by globalization theorists to engage with and unpack it, so as to create (rather than merely presume the existence of) a genuinely shared understanding between theorist and audience. To deny or simply ignore globalization's contestability is not only to impose one's definition of globalization upon others, but also to conceal alternate (and equally valid) understandings of the meaning of globalization. While the former effect is heavy handed (irrespective of whether it is or is not persuasive), the latter effect is evasive and dishonest.

Acknowledging the contestable nature of the term does not necessarily require globalization to be emptied of its intended content, or mired in relativism, eschewing "objective" evaluation. In other words, recognizing the problematic task of defining globalization does not prevent one from infusing the term with definitional specificity. A theorist is still free to proffer her particular definition of globalization. But by doing so while simultaneously acknowledging the existence of other Globalizations, she is better positioned to make the case why her own definition is normatively and descriptively preferable to competing definitions. By differentiating her characterization of globalization from that of others, she can better defend her definition of globalization and persuade us of its merit. In sum, a critical methodology of globalization both recognizes the contestability of the term in order to create a genuinely shared understanding of globalization, and advances a definition of globalization which accounts for its limitations, omissions, assumptions, and predilections vis-à-vis other accounts of globalization. Such a definition erects an internal defense to its critics without sacrificing its definitional specificity.

\section{B. Normativity}

In addition to recognizing the contestable nature of the term "globalization," a critical methodology of globalization also recognizes that normativity cannot be detached from either the performance of globalization theory or the concept of globalization itself. The reason, put simply, is that pure description, absent normativity, is a fiction. Any descriptive account of globalization will be made through a process of evaluation-namely, the deliberate selection, omis- 
sion, or rejection of definitional criteria by a globalization theorist according to that theorist's normative assessment of the value of each criterion. No process of description-whether of globalization or any other social construct-can be undertaken without such an evaluation. Moreover, this evaluation will always be a normative process. That is to say, theorists will inevitably ascribe a value, positive or negative, to each criterion considered, with a positive value ascribed to those definitional criteria which are selected, and a negative value to those rejected. The attribution of positive and negative values to the criteria of globalization considered is inescapable. Globalization theorists are human beings who impute, knowingly or unknowingly, their understandings of and judgments about the world they study to the object of their study. A critical methodology of globalization is one which expressly recognizes, and thereby concedes, that any description of globalization will be a normative one.

\section{Contextualizing Power and Inequality}

Finally, a critical methodology of globalization indexes the definition of globalization to the social relations undergirding it at both the local and global levels. " Such a methodology recognizes that globalization theory cannot be performed in a social, political, cultural, or economic vacuum. Accordingly, definitions of globalization are situated in the context of the power and inequality characterizing both contemporary and historical social relations. This methodology pays particular attention to social inequality - an often neglected ${ }^{112}$ but persistent facet of past and present social relations—as a "yardstick of human

111. See, e.g., Ruth Buchanan, 1-800 New Brunswick: Economic Development Strategies, Firm Restructuring and the Local Production of "Global" Services, in Globalizing Institutions, supra note 21 , at 53 (documenting the entwined relationship between local and global processes in a case study of call centers in New Brunswick); see also Legal Theory, supra note 4, at 5 (explaining that "[r]he global does not exclude the local, but rather they interact in very complex sometimes contradictory ways"); Eve Darian-Smith, Power in Paradise: The Political Implications of Santos's Utopia, 23 L. \& Soc. InQuiRY 81, 115 (1998) (underscoring the point that one person's "local" is another person's "global" and vice versa).

112. See Ngaire Woods, Order, Globalization, and Inequality in World Politics, in IN equality, Globalization, and World Politics 8 (Andrew Hurrell \& Ngaire Woods eds., 1999) (“Traditional investigations into world order have tended to neglect the issue of inequality."). 
progress." ${ }^{113}$ Such inequality is often the result of the uneven allocation of power and resources in and among groups and societies. Power differentials along the lines of sex, class, sexuality, religion, race, nationality, nation, geography (NorthSouth), and culture constitute the backdrop against which theorists create and promote conceptualizations of globalization. ${ }^{14} \mathrm{~A}$ critical methodology of globalization recognizes that social relations involve conflict along these and other cleavages, and that globalization will therefore involve the creation of winners and losers. ${ }^{115}$

As globalization theory is necessarily a prescriptive project-pure description being a fiction-it is necessarily implicated in the allocation of power and distribution of resources in society, whether local or global. A critical methodology of globalization is therefore one that not only recognizes the political consequences of advancing a particular globalization "definition-strategy," but also explicitly accounts for those consequences. Such a methodology recognizes the (potentially) material relationship between globalization theory and social relations by noting, for example, that responses to globalization "are not so much responses to globalization...per se, but to particular understandings and constructions of globalization." 116 In light of this relationship, a critical methodology of globalization would approach globalization theory "with a view to ascertaining [the theory's] (re)distributive properties," 117 local and global. Furthermore, recognizing its own political significance-namely its ability to affect or sustain the distribution of power in the local and global context-a critical

113. See Barry K. Gills, Overturning Globalization: Rethinking the Politics of Resistance, in GLOBALization and Social Change 227, 246 (Johannes Dragsbaek Schmidt \& Jacques Hersh eds., 2000) ("There is no social progress without reform, and the reduction of poverty and inequality are yardsticks of human progress, not the unbridled accumulation of private wealth.").

114. See Gil Gott, Critical Race Globalism?: Global Political Economy, and the Intersections of Race, Nation, and Class, 33 U.C. Davis L. Rev. 1503 (2000); see also Chantal Thomas, Globalization and the Reproduction of Hierarchy, 33 U.C. Davis L. Rev. 1451 (2000) (providing a perspective on the relationship of "globalization" and "globalization theory" to existing hierarchies based on race, class, geography, and nation).

115. Santos, supra note 10, at 135 ("I start from the assumption that what we usually call globalization consists of sets of social relations; as these sets of social relations change, so does globalization.... [I]f globalizations are bundles of social relations, [they] are bound to involve conflicts, hence, both winners and losers.").

116. See Hay \& Marsh, supra note 35 , at 8.

117. See Kerry Rittich, Transformed Pursuits: The Quest for Equality in Globalized Markets, 13 Harv. Hum. Rts. J. 231, 240 (2000). 
methodology of globalization will deliberately eschew "a culture of tolerance for inequality." 18 Such a methodology will instead be concerned with praxis--the relation of theory to practice-and with identifying the potentialities of furthering social equality "as well as the dangers of greater domination, oppression and destruction." 119

\section{Conclusion}

It has been suggested that "[g]lobalization has inaugurated a new phase in the copenetration of theory and practice, knowledge and power." ${ }^{120}$ Whether a part of this new phase or not, globalization theory is knowledge springing from contemporary and historical social relations-knowledge imbued by power relations and social inequality. Such knowledge is not absolute ${ }^{121}$ but is derivative in nature, stemming from a particular spatial, temporal, cultural, social, economic, and political context. By distinguishing between globalization and Globalization, this paper has argued that globalization theory, performed by globalization theorists, cannot be reduced to a descriptive exercise of an objective phenomenon, "globalization." Rather, it is argued that the object of globalization theory is a contestable concept, prompting globalization theorists to proffer divergent definitions of the term, each with different strategic implications. Put simply, different conceptions of globalization call-explicitly or implicitly-for different responses to globalization. Globalization prescription is inescapably contingent upon globalization description. As mentioned previously, this need not create a crisis in globalization theory, nor paralyze individual theorists' attempts to address globalization, nor result in a turn to "postglobalization." A critical methodology of globalization, if adopted, will allow for globalization theorists to continue addressing their object of study, mindful of its

118. See id. at 261 (suggesting that "a culture of tolerance for inequality" may be produced by market reform claims which externalize their redistributive effects, such as the creation or exacerbation of inequality, or which insist that certain spheres (the economy or market) are or ought to be "politics free" zones).

119. See Kellner, supra note 3, at 26 (delineating a "critical theory of globalization" which attempts to identify these dangers). Although I incorporate this goal into my "critical methodology of globalization," this paper does not share Kellner's approach to or definition of globalization.

120. See Rajaee, supra note 105, at 10.

121. But see Santos, supra note 10, at 132 ("Once decontextualized, all knowledge is potentially absolute."). 
contestability, normativity, and origin in local and global social relations. Such a methodology's import becomes clear if it proves true that "[t]he struggle to define [globalization's] meaning will structure much of the politics of the twentyfirst century." 22

122. William K. Tabb, The Amoral Elephant: Globalization and the Struggle for Social Justice in the Twenty-First Century 13 (2001). 
